\title{
Barriers to Educational Pursuits of Refugee Claimants in Canada: The Case of Ghanaians
}

\author{
Edward Opoku-Dapaah
}

This paper examines the barriers that Ghanaian refugee claimants in Canada face in their determination to obtain formal education and makes certain recommendations. "Schooling," in this context, means more than initial language andbasicskills training offered to refugees. Studying, however, means utilizing an established academic setting to acquire knowledge and skills essential to a career in Canada. This includes upgrading and pursuing graduate studies in universities to meet the standards expected in Canada. In short, for refugees with or without prior academic attainment, formal education entails furthering their studies, or enrolling in academic institutions to pursue careers.

Information for this paper is derived from the author's observation and participation $^{1}$ within the Ghanaian refugee community between 1986-90. The paper is also based on interviews with eighty Ghanaian refugees in Toronto. Between October and December 1990, fifty men and thirty women were interviewed. This ratio reflects the gender make-up of Ghanaian refugees in Canada. The eighty respondents were randomly selected from Ghanaian refugees located in North York, Rexdale, Etobicoke and Brampton, all in metropolitan Toronto. Forty-eight or 60 percent of these respondents arrived in Canada as refugees in 1986. The remaining 32 or 40 percent came in 1987. The refugees have been in Canada relatively long enough to become familiar with the Canadian setting.

The main goal in our interviews was to ascertain which factors affected the determination of these refugees to seek further education in Canada. The small size of our sample does not allow

EdwardOpoku-Dapaah is a Research Associate with the Centre for Refugee Studies. definitive conclusions. Nonetheless, the information received provides a rich insight about the problems that confront Ghanaians (and possibly other refugees) in their determination to study in Canada.

The flight of Ghanaian refugees to Canada is a new phenomenon. The main forces behind their influx has been the suppression of the opposition, political persecution and massive arrests by the current military regime-the Provisional National Defence Committee. The intolerance and swift "revolutionary" measures taken against professional groups, traders, religious sects and students haveall played a part. Ghanaian refugees have also gone to neighbouring African nations and destinations in Western Europe. The late 1980s however witnessed an unprecedented influx of these people into Canada. As shown in Table 1, Ghanaian refugee claims rose from twenty in $1984-85$ to 2,233 in 1986 88.

The Immigration and Refugee Board of Canada maintains there have been over 8,000 Ghanaian applicants since 1986, two-thirds of whom are caught up within the huge refugee backlog awaiting a final decision. ${ }^{2}$

Based on a four-tier classification scheme, the educational background of Ghanaian refugees looks like this: Category A: None - 6 (2 percent); Category B: Secondary School or Less 115 (38 percent); Category C: Nonuniversity Certificate or Diploma 148 (48 percent); Category D: Advanced Diploma, University and Postgraduate 38 (12 percent) ${ }^{3}$ Sixty percent possess a qualification beyond the secondary school level. Not only do males form an overwhelming majority of Ghanaian refugees in Canada, they are also overrepresented in the higher echelons of educational attainment. Prior educational experience of our 80 respondents reflects the general record of Ghanaian refugees in Canada as a whole. Three hold a university degree, fifty-two have finished college or secondary school, twenty-two are elementary graduates and three have had no schooling at all. In spite of this impressive record, a detailed analysis of the academic achievements of Ghanaian refugees suggests inadequacies that affect their suitability for the Canadian job market.

Firstly, Ghanaian education is academically focused, meaning much emphasis is placed on cultivating theoretical intellectual values and ideals. Schools are unable to equip students with adequate skills, even when those skills are essential elements of the curriculum. A respondent with a bachelor's degree in computer science, for example, indicated that a lack of computers has ensured that students internalize computer theory without acquiring any practical knowledge about how to operate one. This implies that even the educated Ghanaian refugee is

\begin{tabular}{|lr|}
\multicolumn{2}{|c|}{ Table 1 } \\
Ghanaian Refugee Claims \\
in Canada* \\
Period & Total \\
April 1984 - March 1985 & 20 \\
April 1985 - March 1986 & 597 \\
May 1986 - March 1987 & 1,072 \\
April 1987 - Feb. 1988 & 1,161 \\
Total claims & 2,850 \\
*Claims received by the Refugee Status \\
Advisory Committee 1981-88. \\
Note: Not all time periods are 12 months in \\
duration. \\
Source: Refugee Status Advisory Committee \\
\hline
\end{tabular}

Refuge, Vol. 12, No. 3 (September 1992) 
often not equipped with adequate skills to function in this high-tech society.

Secondly, there is very little occupational specialization within Ghanaian education. There is no functional relation between education and the employment market. Ten college graduates we interviewed did not study with the objective of achieving any specific career, nor could they determine where they could utilize their knowledge.

Thirdly, the sociocultural arrangements in Ghana supports education of men over education for women. ${ }^{4}$ Approximately 4 percent of Ghanaian female refugees in Canada finished an advanced degree or diploma, 26 percent finished secondary school or college, 55 percent finished elementary school, and 14 percent have no schooling. On the other hand, approximately 8 percent of male refugees possess a university degree or advanced diploma, 65 percent finished secondary and college education, 23 percent finished elementary, and 4 percent have no education. A female respondent commented that the enormous stigma attached to being an illiterate male ensures that families will spend more on education for men than on education for women.

Lastly, Ghana's educational institutions, based on the British colonial system, still remain excessively structured. The institutions are still committed to training people for jobs within the government bureaucracy, as opposed to imparting entrepreneurial skills. Greater emphasis is placed on disciplines in the liberal arts than on the sciences, technology and professional disciplines, such as banking, marketing, business administration and so on.

This situation has not enabled an educated Ghanaian refugee in Canada to gain employment based on previous academic training. Well-educated Ghanaians often become factory workers or taxi drivers. Three people with bachelor's degrees in computer science, geography and political science are now engaged in taxi driving, packaging and a courier service respectively. Several college and elementary graduates are engaged in activities ranging from taxi driving, flyer distribution and factory work to cleaning services. Even in situations where their academic knowledge qualifies them for better positions, superfluous obstacles have been placed in their way. For example, prospective employers have been unwilling to recognize their qualifications because they were obtained in Africa. The implication is that their prioreducational attainments have not been an asset in their quest for desirable jobs. Immigration officials and social workers have been quick to point out the impressive educational backgrounds of Ghanaian refugees, but have conveniently ignored their futile attempts to gain employment on the basis of that education.

For the Ghanaian refugee in Canada, the probability of pursuing any career depends on embarking on an educational program in Canada. From the outset, these refugees are at a disadvantage psychologically and materially after being displaced from a developing society with its traditionalism and particular values, into this industrialized setting. Consequently, the importance of education cannot be overemphasized.

The refugees themselves realize the importance of education in assisting their upward mobility. An overwhelming number of those we interviewed indicated that education is their first priority, and that they want to pursue academic careers. They realize that they can never have any comfortable future in Canada if they remain in their current socioeconomic situation. Their inability togetjobsbased on their pasteducational attainment has also motivated them to pursue an education in Canada. They also declared that back home in Ghana most college and elementary school graduates usually further their education by obtaining a university degree or an advanced diploma.

Unfortunately, their determination to seek education has been plagued by prominent barriers at both the institutional and sociocultural levels. The most outstanding problem concerns their uncertain immigration status. The sheer number of refugee applications and the complicated process for handling them has created a huge backlog of over $90,000^{5}$ as of 1991 . The determination of refugee status takes between a year to three years. In spite of the fact that the people in our sample have been here for three to four years, only twenty-one of them have completed the refugee application process, while fifty-nine are still caught in the refugee backlog. For most of this waiting period, which could range from one to two years, refugees are deprived of work permits as well as the necessary authorization to embark on studies. ${ }^{6}$ Even when permission to study is obtained while waiting for the outcome of a refugee claim, the uncertainty of their status in Canada poses a barrier to undertaking an academic program.

Effects of the slow processing of claims on embarking on an educational program was evident from responses received. Thirty-one males and seventeen females in our sample were caught in the anxiety and uncertainty of waiting for the outcome of their refugee hearing before undertaking an academic program. On the other hand, three males, whose applications for refugee status have been approved, were finalizing their enrollment at York University, George Brown College and Humber College, all in Toronto.

The second problem mitigating the quest for education by Ghanaian refugees has been the "tendency of immigration officials and social workers to treat education as a luxury compared to other areas of assistance."7 Throughout the waiting period in the backlog, whatever counselling is available deals only with rent and emergency relief; further education is deemed unattainable by the refugee over the short term. The wisdom of prioritizing food and shelter in the early days of arrival in Canada is self-evident. However, postponing educational counselling only serves to make it a much larger problem in the long term. One example is the case of a student who stopped school due to displacement. Initial counselling and assistance should facilitate the continuation of schoolbefore knowledge 
is lost or a whole academic career is jeopardized.

The third problem deals with the initial orientation services provided to refugees. Realistically this discourages long-term educational pursuits. Through employment centres, the federal government provides language courses and basic skills orientation for those intending to enter the labour force. According to the 1989 immigration manual, Sponsoring Refugees, such language training is beneficial since "fluency in English or French will help counter feelings of alienation, loneliness and dependence." 8 On the contrary, in ourestimation, such a policy, which links language and basic skills to employment, is too short-sighted and fails to recognize that only when a holistic educational assistance program is adopted can the social, economic and psychological problems of refugees be realistically addressed. Also, such extremely basic training prepares refugees only for lowlevel jobs. This carries the unfortunate consequence of channelling people who are already in a vulnerable position into the weakest sectors of the economy, with little reward or incentive to pursue higher education. Many refugees and Third World immigrants who entered the job market without any particular skills have been unable to make any headway socio-economically, ${ }^{9}$ nor have they been able to embark on any career advancement through education.

Ghanaian refugees, like other displaced persons in Canada, suffer from a fundamental flaw in Canadian immigration policy-"the lack of a definite or precise policy on refugee education." 10 There is no policy or specification on how and when a refugee claimant can goto school in Canada, even though refugees have been arriving in this country for years. Since refugee claimants are not visitors or foreign students, they do not qualify for student authorization, which would enable them to study. On the other hand, since refugees in the backlog are neither Canadian citizens nor landed immigrants, they are ineligible to enrol in schools on their own volition. Woefully, Canadian immigration policy is silent on this issue. The law does not confer any educational rights on refugees. The 1986 Immigration Manual, IE 8.22, Section 1 on "Refugee Claimants and Their Dependants Attending School," states that "there is no legal way to authorize such persons [that is, refugees and their dependants] to attend school. The law simply does not cover their situation." 11

In the absence of a definite policy, Section 3-4 of the 1986 Immigration Manual characteristically gives immigration officers the right to grant to refugee claimants, when necessary, a "no objection" letter to enable them to enrol in schools. ${ }^{12}$ Such a situation is chaotic. Not only has the Immigration Act failed to provide a clear way out of this ambiguity, but it has also left it to the whims and caprices of immigration officials. By what criteria are these officials supposed to grant permission when necessary? How do we ascertain whether such decisions are justifiable or not? How do we ensure that such a ruling, which has consequences for a refugee's future, will be made in the interest of a refugee? How competent are these officials when it comes to ruling on issues pertinent to education? By failing to adopt a definite policy on such a crucial issue, the federal government has disregarded the importance of refugee education. Potential students who have been denied "no objection" letters have no place to go to seek redress or to pursue their ambition.

There are formidable financial barriers to Ghanaian refugees' access to education. An overwhelming majority of these people are employed at the lowest level of the economic strata where income level is around the poverty line. Caught in a situation where annual income can hardly cover daily living expenses, tuition and other academicrelated costs become impossible to bear. This situation is made worse by the fact that unless they have the necessary approval from immigration officials, refugees are charged foreign students fees, which are three times higher than the domestic rate.

A survey conducted by Refuge ${ }^{13}$ in 1982 to find out what financial assistance was available for postsecondary education for refugee students with landed immigrant status uncovered a series of preconditions that placed such assistance beyond their reach. Amazingly, such preconditions still exist today. The survey established that, in almost all the provinces, even after residency status has been granted, the former refugee must work a year or two in the labour force before qualifying to apply for financial assistance. ${ }^{14}$ In reality, a Ghanaian refugee who has waited for a year in the backlog without a work permit, even if he or she is granted status

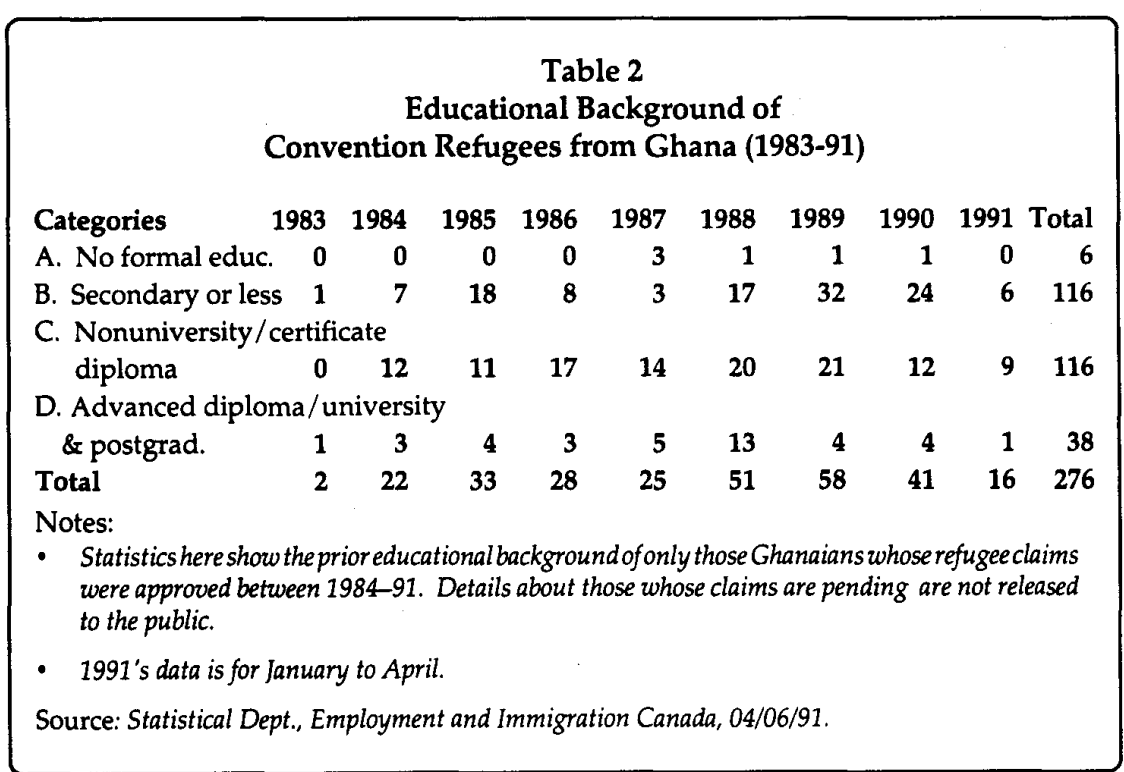

Refuge, Vol. 12, No. 3 (September 1992) 
in the second year, will have to work for a year before qualifying for financial assistance in Nova Scotia, NewfoundlandandNewBrunswick. In Ontarioand British Columbia, the person qualifies for assistance a year after receiving permanent status. In the latter situation, if the person waited in the backlog for two years, he or she must wait one more year before being eligible for financial assistance. Such a complex and problematic arrangement surrounding funding may create frustrations and loss of interest in education.

For a refugee in this country, access to educational facilities depends largely on access to information. This is woefully lacking. Only twelve out of the eighty respondents received any information or counselling about educational opportunities from their social workers. Two respondents remarked that, even though they have consistently consulted their social workers for a year, they havenever been given any counselling concerning education. An ambitious student who contacted social services about going to school was referred to the immigration department. He went there, only to be referred back to social services. Still no adequate educational counselling was provided. The sources of educational counselling available to the refugees in our sample were social services (twelve people), schools and universities (nineteen), and informal sources (twenty-three). The rest received no counselling at all. Those who received information from schools indicated the highest level of satisfaction with the information received.

For some refugees, the lack of documents to establish their academic attainments created confusion as to where to place them within the Canadian education system. ${ }^{15}$ When reassessment resulted in their being placed at levels beneath them, it created disillusionment and frustration, leading to withdrawals.

Social cultural forces have also impeded the motivation of Ghanaian refugees to study. Female refugees have been the major victims. Besides their occupations outside the home, women are also expected by their husbands to do domestic duties. Wives in our sample indicated that, even after they and their husbands have both worked for eight hours in their regular jobs outside the home, it is still the women's sole responsibility to prepare dinner.

This combination of jobs and housework gives them very little time to pursue even part-time studies. For women with children, the situation is worse. Two out of every three Ghanaian refugee women have had a child since coming to Canada. Care giving is permanently perceived to be women's responsibility. In the absence of help from the extended family, as in Ghana, refugee women spend more time performing maternal and domestic duties than their male partners. Female

\section{Wives in our sample indicated that, even after they and their husbands have both worked for eight hours in their regular jobs outside the home, it is still the women's sole responsibility to prepare dinner.}

refugees' education is more likely to be affected by the absence of affordable child-care facilities than that of their male counterparts. Clashes between class schedules, the picking up and dropping off of children, and other responsibilities, deters most women from pursuing academic careers. ${ }^{16}$

Ghanaian female refugees' career plans are also held in check by sociocultural practices that make the wife subordinate to the husband. Within the refugee family, the husband normally earns more income than the woman, due to inequalities in the economic system. The husbands have also been instrumental in bringing their wives over to Canada. A combination of these give husbands greater control over the affairs of their wives.

Wives' career plans in particular require the approval of their husbands, which is not always forthcoming. Husbands may insist that their wives work full-time to enable them to raise money for investments or other plans. Information received from some husbands in our sample indicated that because it costs so much to bring their wives over here, husbands believe that wives should work to settle incurred debts and/or raise capital for the future.

Almostall the husbands believe that, although wives do not earn enough, if they stopped working to study, it will affect total family income and livelihood. The husbands would rather pursue studies first.

Of the thirty women interviewed for the project, only one has pursued studies since coming to Canada in 1987. That woman tooka six-month course in health care. None of the others had undertaken any studies. Twenty-one of them intended to go to school, but did not know when.

Ghanaian refugee women are already comparatively less educated earn less income, and possess less opportunity for schooling. The feminization of illiteracy and poverty is worsened by inequities within marriages.

The educational plans of some Ghanaian refugees have also been affected by their preoccupation with helping their relatives back home. Since most of the refugees were the breadwinners before their flight abroad, they send money to parents, children, spouses and even extended relatives in Ghana. Realizing the dire economic problems backhome, Ghanaian refugees have deemed it socially appropriate, if not obligatory, to cover expenses such as medical costs, home maintenance and domestic needs of their families.

There are some who are interested in the economic opportunities available in Toronto and do not see education as a priority. To those in this last category, resettlement in Canada means striving to amass as much wealth as one can to afford a relatively comfortable life, compared to the deprivation and hardships that characterized their lives back home.

A combination of some of the above problems have served as barriers making education an impossible dream for Ghanaian refugees. Yet education's unquestionable benefits to refugees and 
society as a whole, as well as its humanistic significance, does not warrant its abandonment. For people displaced from their homeland into a new environment, education can lead to furtheropportunities. Education can bea key factor in providing the orientation needed for integration and adjustment into Canadian society. The respondents in our sample work as an unskilled labour force in factories and service occupations. The only way to promote occupational mobility is through education. Having lost their traditional ties and web of social networks, education can boost morale and meet other psychological needs of African refugees in Canada.

In light of the need for and the significance of refugee education, the following recommendations are suggested. First and foremost is the need for a national policy on refugee education. This should specifically address issues pertinent to when refugees can apply to go to school, so that their status will not serve as a barrier. Pegging such a time at six months after the arrival of the refugee in Canada would be adequate, since needs for shelter, food and jobs would have already been dealt with.

Such a policy should also identify one organization (such as the immigration department or social services) that would be responsible for providing information and educational counselling. Counselling should be provided early, not later, because education can help individuals to cope with the trauma of exile. Such counselling should emphasize academic opportunities and future prospects. The role of educators will be essential in advising on course content and immersion courses and evaluating previous academic qualifications to determine appropriate levels of placement within the Canadian education system. There should also be interdepartmental cooperation between the Department of Social Services and Immigration on education. This will ensure proper coordination and remove the frustration of going from one agency to the other.

Another recommendation concerns funding. We recommend that barriers be removed and that refugees be granted access to funding as early as possible. As well as being a disadvantaged group, refugees are also not socially and economically established. Making financial assistance contingent on a job or the length of stay, etc., will lead to frustration. The federal government is currently spending $\$ 179$ million to process the huge refugee backlog. ${ }^{17}$ Part of this could be allocated to assist in refugee education and resettlement in general.

Meeting the educational needs of Ghanaian refugees is not a subject that can be adequately determined by bureaucrats in national headquarters. A consultation with community-based groups such as the Canadian Newcomer Assistance Centre (CANACT), which deals with African refugees daily, can produce vital information to assist in planning strategies.

Ghanaian refugees in Toronto have a host of recreational and ethnic associations, notably the Canadian Ghanaian Organization, the High Society, Ghana Refugee Group, etc. These associations are extremely informal. They bring together people with shared backgrounds and interests, and facilitate networking in the search for jobs, accommodation, immediate financial assistance and entertainment. In dealing with the sociocultural factors affecting refugee education in Canada, these associations can be used as a medium for assessing the nature of the problem. They can be used as reliable channels for explaining to refugees the need for changes in social cultural practices. These associations can also assist in involving the refugees themselves in resolving these problems.

We hope that consultation between the three groups-state bureaucrats, community-based organizations and representatives of refugee associationscan produce a working agenda to assist in shaping an effective policy towards refugees' educational needs. It will also ensure that the key players in this issue are involved in the resolution. Without cooperative consultation, education will remain an impossible dream for Ghanaian refugees in Canada.

\section{Notes}

1. J. Lofland and L.H. Lofland, Analyzing Social Setting: A Guide to Qualitative Observation and Analysis (Belmont: Wadsworth Publishing Co., 1984):12-13. The authors outline the merits of combining informal interviews with observation - the approach was adopted in this work. This was facilitated by the author's Ghanaian background and community involvement.

2. Employment and Immigration Canada, Estimates, 1990.

3. Employment and Immigration Board, Statistical Data, 1991.

4. Rhoda Howard, Human Rights in Commonwealth Africa (Rowan and Littlefield, 1986):184-202.

5 Bernard Valcourt, Minister of Employment and Immigration, Refugee Backlog Clearance Programme news release (October 4, 1991).

6. Employment and Immigration Canada, Immigration Manual IE 8.0, paragraphs 8.14-8.24.

7. World University Service, Refugee Education: A Case for Internal Action (1987):7.

8. Employment and Immigration Canada, Sponsoring Refugees: Facts For Canadian Groups and Organizations (1989): 10.

9. Anthony H. Richmond, "Comparative Perspectives on Immigration and Ethnicity" (September 1991):7. Unpublished paper presented at the Urban Institute in June 1991.

10. Employment and Immigration Canada, Refugee Claimants and Their Dependants Attending School - Immigration Manual, IE 8.22 (Ottawa: Employment and Immigration Canada, December 1986): 17.

11. Ibid.

12. Ibid.

13. Centre for Refugee Studies, York University, Financial Assistance Available in Canada to Post-Secondary Refugee Students. Survey conducted by Refuge in 1982.

14. Centre for Refugee Studies, op. cit.

15. Kathryn McDade, Barriers to Recognition of Credentials of Immigrants in Canada Discussion Paper 88.B.1 (Ottawa: Studies of Social Policy, Institute for Research on Public Policy).

16. Ontario Women's Directorate, Report on the 1987 Community Workshops with Visible Minority and Immigrant Women (Ontario: Ministry of Citizenship, 1987):35.

17. Valcourt, news release, October 4, 1991. 